\title{
Personality and Pay Satisfaction: Examining the Relationship of a Sample of Blue Collar Workers Personality and Their Pay Satisfaction Levels
}

\author{
Blake E. Nielson, Ph.D. (Corresponding author) \\ Department of Management and Marketing, Missouri Southern State University \\ E-mail: nielson-b@mssu.edu
}

J. R. Smith, DBA

Department of Management and Marketing, Jackson State University

E-mail: jrsmith@jsums.edu

Received: August 16, 2014

Accepted: Sep. 21, 2014

Published: October 1, 2014

doi:10.5296/jmr.v6i4.6318

URL: http://dx.doi.org/10.5296/jmr.v6i4.6318

\begin{abstract}
Compensation plans are the tool that unites employers and employees together in one of the most important exchange processes that happens in organizations. Pay satisfaction is usually achieved when employees feel that they are being paid fairly compared to their referent others. It is desirable for organizations to enhance employee pay satisfaction because it can enhance productivity and commitment to the organization. This study addressed the pay satisfaction process by analyzing the relationship of personality and pay satisfaction. The mediator variables of amount realized and pay perceptions were also analyzed in the pay satisfaction and personality relationship. A sample of 251 blue collar workers was collected. Structural equation modeling was utilized to analyze these relationships. The results indicated that personality can have both a positive or negative relationship with pay satisfaction depending on the personality type. There was evidence that extraversion had a positive relationship with pay satisfaction, while conscientiousness, neuroticism and openness and a negative relationship with pay satisfaction. The study's limitations and avenues for future research were addressed.
\end{abstract}

Keywords: Personality, Pay Satisfaction, Pay Perceptions, Pay Amount, Equity Theory, Discrepancy Theory. 


\section{Introduction}

There is no doubt that employees' satisfaction with their pay has always been a primary concern to employees as well as employers (Williams, McDaniel, \& Nhung, 2006). Dulebohn and Werling (2007) stated that one of the most important relationships between employers and employees is the compensation exchange or transaction process. Human resource management plays an important role in this process as the branch of the organizational science that deals with all the policies, regulations, and practices between employers and employees. Human resources as well as company executives have the task of ensuring that compensation will enhance job satisfaction as well as drive productivity (Kirkland, 2009).

Although people work for many different reasons including purpose and intrinsic rewards (Lopes, 2011), most work because they depend on their salary or wages to exist (Dulebohn \& Werling, 2007). Similarly, management hires and compensates people because they are often the greatest assets (Branson, 2010). Organizations need to carefully design, communicate, and manage their own compensation techniques in order to align the organizational goals with the employees' best interest. Because this is no easy task, there are issues that executives, managers, and human resource personnel experience in trying to effectively and efficiently design and manage the employee compensation plan.

\section{Pay Satisfaction}

There are two major pay satisfaction theories. The first is equity theory that was started by Homans (1961) and enhanced by Adams (1963b). Homans (1961) asserted that equity results when an individual obtains rewards proportional to his or her investments, less costs, when compared to the other party in the exchange relationship. Adams (1963b) enhanced this work by declaring that individuals evaluate the fairness of their outcomes using an equity rule whereby they compare their own input-outcome ratios to a referent or comparison other. Individuals perceive equity or fairness when the ratio or balance of their outcomes to their inputs is equal (Adams, 1963b; Adams, 1965; Walster, Walster, \& Berscherid, 1978).

There are implications for organizations to consider based on this theory. Researchers in equity theory found that workers may react when they felt there was an inequality. For example, workers would attempt to achieve equity through actions such as altering inputs, altering outcomes, adjusting their evaluations of their inputs and outputs, using a different comparison other, by using psychological justifications, or by withdrawing from the organization (Adams, 1965; Clark, 1958). Data based research efforts generally supported the theory's predictions of employees taking action to restore equity (Gerhart \& Rynes, 2003). Empirical evidence has also been advanced in the literature noting that overpayment will improve work, and underpayment will cause negative behavior (Cowherd \& Levine, 1992; Pfeffer \& Davis-Blake, 1992; Pfeffer \& Langston, 1993). This type behavior in the work place was found to hold true for people as well as teams (Thompson, 1997). Because of the consequences of these theoretical underpinnings, it is vital for organizations to ensure employee pay satisfaction. 
Discrepancy theory is the second major pay satisfaction theory. In some instances this theory has been stated as an extension of equity theory (Dulebohn \& Werling, 2007). Discrepancy theory hypothesizes that pay satisfaction is a function of the discrepancy between perceived pay level and the amount the employee believes they should receive (Brandon, 1992; Gerhart \& Milkovich, 1992; Lawler, 1971). Specifically, employee pay satisfaction is evaluated by their subtracting the amount they are paid from the amount they believe they should be paid (Dulebohn \& Werling, 2007). Although there are similarities between the two theories, there are quantifiable differences. For example, discrepancy theory includes the additional variables such as job level, level of responsibility, job difficulty, and the factor "valence". (Lawler, 1971). Because there is positive evidence of both theories in the literature, it may be assumed that both theories have merit. However, if management understood all of the constructs of people that may favor one theory over the other, it could lead to better strategic decisions about compensation plans.

\section{Personality}

Personality is one of the constructs that has been under researched in the pay satisfaction literature. In research models addressing pay, researchers have been cautious to include personality as a construct. According to Adler and Weiss (1988), personality research is sometimes held in low regard which may explain why researchers hesitate to include personality in their models. Shaw, Duffy, Jenkins, and Gupta (1999) stated that despite extensive research, few stable predictors of pay satisfaction have been identified, perhaps because pay satisfaction research seldom explored personality or dispositional characteristics as potential antecedents. Mount, Barrick, and Ryan's (2003) work addressed mediational links between personality and criteria of interest using existing constructs such as well-accepted personality traits and motivational constructs.

Although researchers have studied pay level satisfaction for more than 40 years, a comprehensive summary of the pay satisfaction body of research appeared to be lacking. During that time period, there were narrative reviews of pay satisfaction research (Heneman \& Schwab, 1979; Heneman \& Schwab, 1985; Heneman \& Judge, 2000). However, they represented a specific time period rather than a comprehensive review. Meta-analysis studies were advanced that summarized the field of pay level satisfaction and gave direction for future research (Williams et al., 2006; Williams, McDaniel, \& Ford, 2007).

One of the several gaps identified was more empirical data based studies were needed in testing the role of personality in the pay satisfaction model. Only a few primary studies of personality and pay satisfaction exist and they encouraged researchers to include personality in their models of pay level satisfaction and to test these relations in primary research (Williams et al., 2006). They went on to suggest to test Type A/Type B behavior, emotional stability, and conscientiousness as possible personality traits that can affect the overall pay satisfaction model. Since 2006, studies have focused on this meta-analysis and researched some of the gaps that were proposed. Some of these include the relationship between transformation leadership and pay satisfaction (Antoni \& Syrek, 2012), value of total rewards (Hulkko-Nyman, Sarti, Hakonen, \& Sweins, 2012), consequences that stem from pay 
dissatisfaction like turnover (DeGieter, DeCooman, Hofmans, Pepermans, \& Hegers, 2012; Vandenberghe \& Tremblay, 2008) and effective compensation administration (Baker, 2007).

The largest volume of pay satisfaction research has concentrated on ground characteristics as predictors. The results of these studies are varied and generally show that background and individual characteristics (e.g. age, gender, education, and tenure) are inconsistent predictors of pay satisfaction (Judge, 1993; Rice, Phillips, \& McFarlin, 1990; Shaw et al., 1999, Smola, 2003). Even though these articles did not fully study the effects of personality, it was a step in the right direction (Williams et al., 2006).

Even though pay satisfaction and personality have not received adequate attention, other elements of pay and personality have had relevant advances. Some studies have tested the effects of earnings based on the personality variable (Heineck, 2011; Mueller \& Plug, 2006; Spurk \& Abele, 2011) rather than including and testing personality in the pay compensation theory's and satisfaction levels. There have been studies on personality traits by using a DISC (dominance, inducement, submission, compliance) study (Turnasella, 2002) and positive and negative affect (Shaw et al., 1999); however, these studies test traits of a personality, rather than an overall personality.

\section{Methodology}

The focus of this research is to analyze the relationship between a sample of blue collar workers personality and their pay satisfaction. The study will test both the direct relationship and the relationship through mediator variables. The study hypotheses are presented in Table 1 .

Table 1. Hypotheses

$\mathrm{H}_{1} \quad$ There is a significant relationship between personality and pay level satisfaction.

$\mathrm{H}_{2} \quad$ There is a significant relationship between personality and pay level satisfaction through the mediator of pay perception.

$\mathrm{H}_{3} \quad$ There is a significant relationship between personality and pay level satisfaction through the mediator of amount realized.

Table 1 includes the alternative hypothesis for each of the hypotheses. The null hypothesis was that there is no relationship. Figure 1 shows the theoretical model of the hypotheses. 


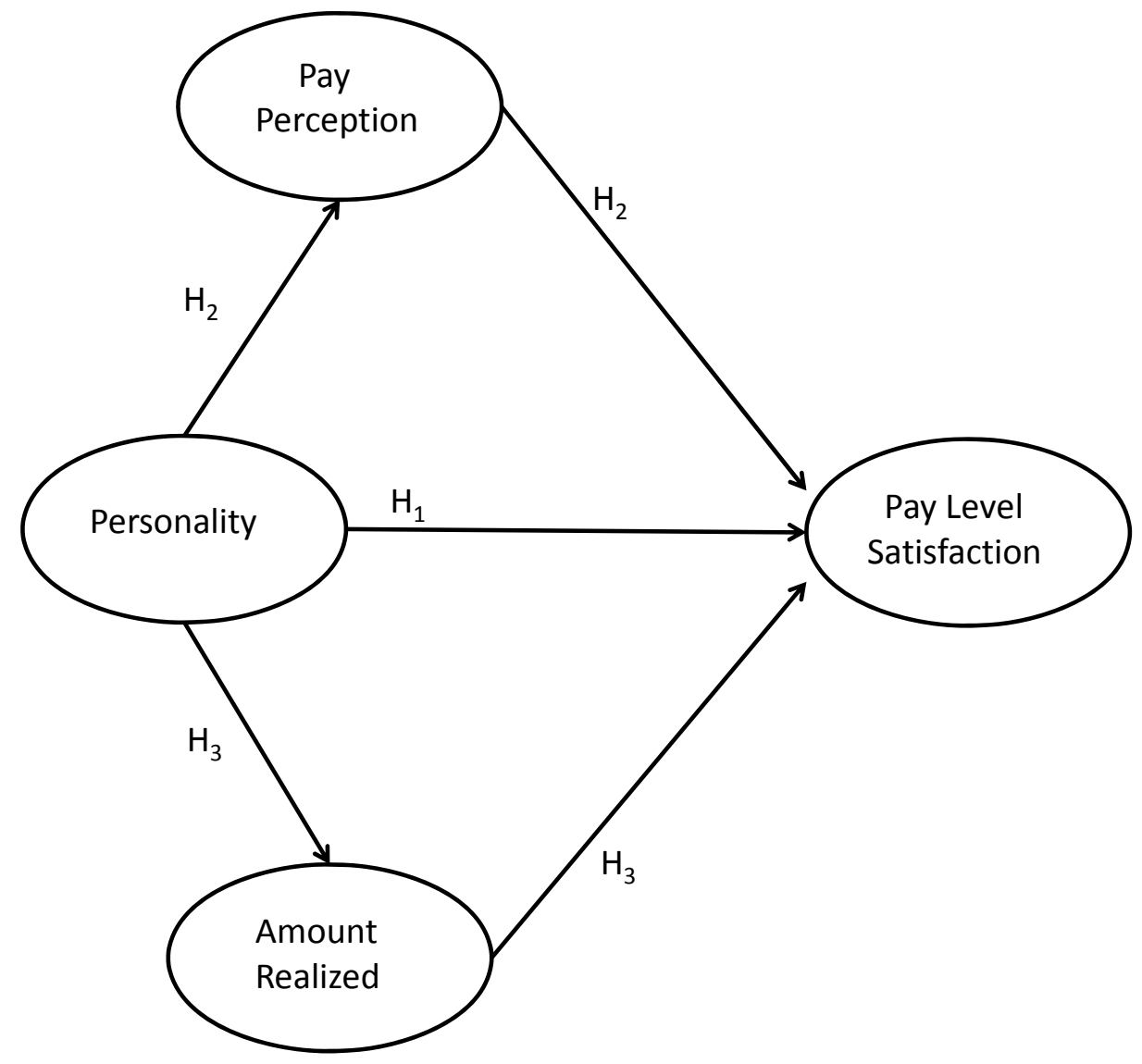

Figure 1. Hypotheses of the Employee Pay Satisfaction Model

This study implemented the Big Five personality profile instrument. This growing acceptance of the Big Five Model has facilitated the resurgence in personality research. Personality is now being used more often as a predictor of organizationally relevant outcomes (Digman, 1997; Penney, David, \& Witt, 2011). This study instrument has been accepted as a standard in the literature (Dudley, Orvis, Lebiecki, \& Cortina, 2006). The pay satisfaction questionnaire was also implemented in this study. The questions were modified to measure pay perceptions, amount realized and pay satisfaction.

The study sample was comprised of 251 blue collar workers. Blue collar workers are typically members of the working class who perform manual labor and earn an hourly wage. It is very important for management to make sure that these workers are very efficient and productive. Blue collar employees work at the ground level of the organization producing goods or services.

Blue collar workers were selected for this study because of the immense interaction continuously displayed by these employees in the workplace. Blue collar workers perform their tasks together in large work spaces. A shop may shut down for lunch break. This down time allows workers the opportunity to interact and discuss job satisfaction and dissatisfaction issues, including pay fairness. 
The state of the economy has impacted the availability of blue collar jobs. A recent study revealed that from the fourth quarter of 2007 to the fourth quarter of 2009 blue collar jobs accounted for $67.1 \%$ of the total number of job losses (Sum, Khatiwada, McLaughlin, \& Palma, 2010). Despite this dramatic change, blue collar jobs are still roughly $20 \%$ of America's employed workforce (U.S. Bureau of Economic Analysis, 2012). Hence, the true attitudinal and perceptual beliefs of blue collar workers chosen for this sample, with respect to job satisfaction and pay, may be confounded by shortage of blue collar jobs in the economy to date.

The sample respondents invited to participate in the study came from a current list of blue collar workers employed in the United States. The sample consisted of individuals who work in factories, construction sites and other manual labor jobs. Sample respondents were required to be currently employed and receive an hourly wage rate.

A computerized structured questionnaire was utilized to gather data from respondents. This questionnaire was delivered electronically to individuals from a list of blue collar workers. A random sample of the blue collar workers were selected and invited to participate in the survey. This sample selection procedure gave each blue collar worker on the list an equal and known chance of being selected to participate in the study. Hence, generalization of study findings may be inferred. A respondent's participation in the survey was fully voluntary and he/she may refuse to answer any part of the survey instrument questions or participate in the survey entirely. All answers were confidential and study results were strictly anonymous.

Structural equation modeling (SEM) was the statistical tool utilized to test study hypotheses. SEM has become a significant way of doing research in the social sciences. SEM is a combination of regression analysis and factor analysis. Hair et al. (2010) discussed some of SEM's advantages in their recent textbook. SEM has the ability to estimate a series of separate, interdependent, multiple regression equations simultaneously. This is a more realistic view of how variables relate to each other. Measurement error can also be accounted for by using two or more indicators for each of the constructs.

\section{Results}

A pilot study was conducted to ensure the survey and the sample would produce significant statistical results. The survey was electronically delivered and 54 participants completed the survey at a response rate of $10.36 \%$. The results indicated that the study design was adequate to produce significant statistical results. Both the factor loadings and cronbach alpha were deemed significant.

Next, a total of 1,156 questionnaires were distributed to the random sample. There were 654 $(56.6 \%)$ that did not start the survey. Another $223(19.3 \%)$ of the respondents were disqualified because they were either part time or not classified as blue collar workers. There were $28(2.4 \%)$ respondents that dropped out during the survey. The final sample size was 251 with a response rate of $21.7 \%$.

Exploratory factor analysis was used to examine the variables factor structure. The main objectives of exploratory factor analysis are to analyze the variables that are formed into 
factors and how well each of the variables loads to the factor. The factor loadings in this analysis are very important. These factor loadings reflect the correlation between the indicator and the factor. The loadings are measured on a scale from -1.0 to 1.0. Hair et al. (2010) gave the following criteria for determining the significance of factor loadings: Factor loadings in the range of \pm .30 to \pm .40 are considered to meet the minimal level for interpretation of structure. Loadings \pm .50 or greater are considered practically significant. Loadings exceeding \pm .70 are considered indicative of a well-defined structure and are the goal of any factor analysis. The KMO is the common measure used to analyze the significance of factor analysis. A KMO measure from 0.90-0.99 is measured as outstanding, from $0.80-0.89$ as very good, from $0.70-0.79$ as average, from $0.60-0.69$ as tolerable, from 0.50-0.59 as miserable, and below 0.49 as unacceptable (Hair et al., 2010).

Table 2 presents the factor analysis for the personality variables. Table 3 presents the factor analysis for the pay variables. The factor analysis produced KMO values of .866 (personality variables) and .927 (pay variables) respectively. The analysis results indicated that all of the factor loadings were greater than .50 and considered significant (Hair et al., 2010). All but five of the variables (EX1, AG4, CO2, PP4 and AMT3) had factor loadings that exceeded .70. However, all of these variables had a loading that exceeded .60 and were kept in the study and validated through reliability analysis and confirmatory factor analysis.

Table 2. Personality Factor Analysis

\begin{tabular}{|c|c|c|c|c|c|}
\hline \multirow[b]{2}{*}{ Variable } & \multicolumn{5}{|c|}{ Component } \\
\hline & 1 & 2 & 3 & 4 & 5 \\
\hline EX1 & .673 & & & & \\
\hline EX2 & .776 & & & & \\
\hline EX3 & .834 & & & & \\
\hline EX4 & .791 & & & & \\
\hline AG1 & & .759 & & & \\
\hline AG2 & & .792 & & & \\
\hline AG3 & & .790 & & & \\
\hline AG4 & & .681 & & & \\
\hline $\mathrm{CO} 1$ & & & .751 & & \\
\hline $\mathrm{CO} 2$ & & & .682 & & \\
\hline $\mathrm{CO} 3$ & & & .735 & & \\
\hline $\mathrm{CO} 4$ & & & .763 & & \\
\hline NE1 & & & & .737 & \\
\hline NE2 & & & & .835 & \\
\hline NE3 & & & & .780 & \\
\hline NE4 & & & & .767 & \\
\hline OP1 & & & & & .837 \\
\hline OP2 & & & & & .711 \\
\hline OP3 & & & & & .762 \\
\hline OP4 & & & & & .788 \\
\hline
\end{tabular}

$\mathrm{KMO}=.866$ 


\section{Macrothink}

Table 3. Pay Perception, Amount, and Satisfaction Factor Analysis

\begin{tabular}{cccc}
\hline & \multicolumn{3}{c}{ Component } \\
\hline Variable & 1 & 2 & 3 \\
\hline PP1 & .848 & & \\
PP2 & .954 & & \\
PP3 & .808 & & \\
PP4 & .633 & & \\
AMT1 & & .890 & \\
AMT2 & & .923 & \\
AMT3 & & .618 & .916 \\
AMT4 & & .733 & .936 \\
SAT1 & & .937 \\
SAT2 & & & \\
SAT3 & & & \\
SAT4 & & &
\end{tabular}

The reliability coefficient was also examined for each of the factors. Cronbach alpha is the most common and widely used measure to access the reliability of each scale. The generally agreed upon lower limit for Cronbach alpha is .70 (Hair et al., 2010). The results from this analysis are presented in Table 4.

Table 4. Reliability of Factors
Construct
Cronbach Alpha $(\alpha)$

Extroversion

.793

Agreeableness

.759

Conscientiousness

.723

Neuroticism

.804

Openness

.789

Pay Perception

.916

Pay Amount

.863

Pay Satisfaction

.948

The Cronbach alpha for all the factors was deemed satisfactory and above the threshold. Next, SEM was utilized to test the study's hypotheses. Agreeableness had no significant results and was removed from the final model. In the final model the error terms for pay perceptions and amount realized were co-varied. The results and fit of the final model are presented in Table 5 . 


\section{Macrothink}

Table 5. Fit and Path Analysis for SEM Constructs

\begin{tabular}{|c|c|c|c|c|c|c|c|}
\hline \multicolumn{3}{|c|}{ Path } & Z Score & P-Value & \multicolumn{2}{|c|}{ Significant } & Value \\
\hline \multicolumn{3}{|c|}{ Extroversion $\rightarrow$ Satisfaction } & 2.623 & .009 & \multicolumn{2}{|c|}{ Yes } & .117 \\
\hline \multicolumn{3}{|c|}{ Extroversion $\rightarrow$ Perception } & 1.232 & .218 & \multicolumn{2}{|c|}{ No } & .086 \\
\hline \multicolumn{3}{|c|}{ Extroversion $\rightarrow$ Amount } & 3.523 & .000 & \multicolumn{2}{|c|}{ Yes } & .263 \\
\hline \multicolumn{3}{|c|}{ Conscientiousness $\rightarrow$ Satisfaction } & -2.124 & .034 & \multicolumn{2}{|c|}{ Yes } & -.094 \\
\hline \multicolumn{3}{|c|}{ Conscientiousness $\rightarrow$ Perception } & -1.899 & .058 & \multicolumn{2}{|c|}{ No } & -.139 \\
\hline \multicolumn{3}{|c|}{ Conscientiousness $\rightarrow$ Amount } & -3.141 & .002 & \multicolumn{2}{|c|}{ Yes } & -.241 \\
\hline \multicolumn{3}{|c|}{ Neuroticism $\rightarrow$ Satisfaction } & -.520 & .603 & \multicolumn{2}{|c|}{ No } & -.022 \\
\hline \multicolumn{3}{|c|}{ Neuroticism $\rightarrow$ Perception } & -2.731 & .006 & \multicolumn{2}{|c|}{ Yes } & -.193 \\
\hline \multicolumn{3}{|c|}{ Neuroticism $\rightarrow$ Amount } & -.183 & .855 & \multicolumn{2}{|c|}{ No } & -.013 \\
\hline \multicolumn{3}{|c|}{ Openness $\rightarrow$ Satisfaction } & -2.021 & .043 & \multicolumn{2}{|c|}{ Yes } & -.083 \\
\hline \multicolumn{3}{|c|}{ Openness $\rightarrow$ Perception } & -2.680 & .007 & \multicolumn{2}{|c|}{ Yes } & -.189 \\
\hline \multicolumn{3}{|c|}{ Openness $\rightarrow$ Amount } & -2.150 & .032 & & & -.154 \\
\hline Perception $\rightarrow$ & atisfaction & & 8.781 & .000 & & & .656 \\
\hline Amount $\rightarrow \mathrm{Sa}$ & sfaction & & 2.452 & .014 & & & .189 \\
\hline Chi-Square & P-Value & CMIN/DF & RMSEA & NFI & GFI & CFI & TLI \\
\hline 793.240 & .000 & 2.382 & .074 & .829 & .820 & .892 & .877 \\
\hline
\end{tabular}

Four out of the five personality traits had a significant relationship with pay satisfaction. Even though the all of the SEM fit values were not perfect, they did indicate some validity of measurement of the constructs. Table 6 shows the study hypotheses and the results that were borne out from the data analysis. 
Table 6. Summary of Hypotheses, Findings, and Results

$\begin{array}{lll}\text { Hypotheses } & \text { Findings } & \text { Results }\end{array}$

$\mathrm{H}_{1}$ : There is a significant relationship between personality and pay level satisfaction.

$\mathrm{H}_{2}$ : There is a significant relationship between personality and pay level satisfaction through the mediator of pay perception.
Supported

Supported satisfaction through the mediator of amount realized. relationship between
personality and pay level relationship between
personality and pay level

$\mathrm{H}_{3}$ : There is a significant
Extroversion had a positive relationship with pay level satisfaction. Conscientiousness and openness had a negative relationship.

Neuroticism and openness both had a significant negative effect on pay satisfaction through the mediator of pay perception.
Supported

$\begin{array}{ll}\text { Supported } & \text { Extraversion had a significant } \\ \text { positive relationship while } \\ \text { conscientiousness and openness } \\ \text { had significant negative } \\ \text { relationship with pay satisfaction } \\ \text { through the mediator of amount } \\ \text { realized. }\end{array}$

\section{Discussion}

The results of the study seem to imply that the findings were similar and additive to the literature that was used to build and justify the pay satisfaction model. This research was designed to implement both equity and discrepancy theories. These theories were used congruently by analyzing pay perceptions of fairness according to the recommendation of Williams et al. (2006). These theories state that pay perceptions of fairness are more important to pay satisfaction than the total amount of compensation. Although both pay perceptions and amount realized had a positive relationship with pay satisfaction in the employee pay satisfaction model, the pay perceptions and pay satisfaction relationship had a much higher statistical correlation than the amount realized and pay satisfaction relationship. This result lent support to the principles of both equity and discrepancy theory (Adams, 1963a; Lawler, 1971). These theories and findings indicate that pay fairness may be more important than total amount of compensation. 
Similar to the study conducted by Spurk and Abele (2011), this research indicated that extroversion has a significant relationship with pay amount. This was also complimentary to the findings reported by Turnasella (2002) in noting that extraversion is the only trait in the Big Five Personality Profile that has a positive relationship with pay valence. Thus, extroverts put more focus on pay than the other personality traits and according to Turnasella (2002) this is the big reason that extraverts typically will have higher salaries.

The results indicated that there was a negative relationship between consciousness, openness, neuroticism and pay satisfaction through either a direct relationship or an indirect relationship. These results may be interesting from a managerial standpoint. The results indicate that extroverts are more likely going to be happy with their pay, while those who are neurotic, conscious, or open may be less satisfied with their pay. Thus, managerial actions could be taken to realize that extroverts will typically be more satisfied than the others.

The pay amount and pay satisfaction relationship was also comparable and additive to past research efforts. Heneman and Judge's (2000) comprehensive review indicated that there had been studies that found there was a relationship between pay amount and pay satisfaction, while others were not able to establish this relationship. The findings reported herein were significant and beneficial to that review. The findings indicated that there is a modest relationship between pay amount and pay satisfaction. The findings were also complementary to Williams et al.'s (2006) pay satisfaction meta-analysis with the actual magnitude of the relationship between the pay amount and pay satisfaction constructs.

\section{Limitations and Future Research}

We must recognize that the sample design poses a limitation on the interpretation of study findings. The sample questionnaire solicited employee self-reported responses. It would have been an ideal data collection technique to measure fairness based on a performance evaluation and actual pay rather than the employee self-reported perceptions.

The combination of the time period of the study and the sample that was collected presents a possible limitation. In the past, a higher percentage of the work force was employed in blue collar labor. Even the recent state of the economy has had an impact on this workforce. For example, a recent study revealed that from the fourth quarter of 2007 to the fourth quarter of 2009 blue collar jobs accounted for $67.1 \%$ of the total number of job losses (Sum et al., 2010).

The random sample selected for this study may have been more satisfied than other time periods because they still have a job while many of their co-workers may have been laid off. Theoretical implications must be addressed as a possible limitation based on the design of the study. This study focused on a combination of equity and discrepancy theory while analyzing the relationship between personality and pay satisfaction. There are other job satisfaction theories that may be important to consider in the pay satisfaction process. For example, expectancy theory (Vroom, 1964) states that for a person to be motivated the following three factors must be linked: effort, performance and motivation. These factors were not treated in this study. 
The treatment of Herzberg (1966) Two Factor Theory may also be a limitation of this study and warrants exploration in future research efforts. This theory states that motivators such as challenging work, recognition and responsibility give positive job satisfaction through intrinsic conditions of the job itself. Hygiene factors such as status, salary, benefits and work conditions do not give positive satisfaction, but can be a cause of dissatisfaction. Although the theoretical underpinnings of these theories are in job satisfaction rather than pay satisfaction, it may be beneficial to analyze if the Big Five personality traits have a role in any of these theoretical processes of satisfaction or dissatisfaction through the pay factors.

Future research should address fairness based performance metrics rather than self-reported data. It would also be beneficial to compare self-reported and metric/supervisor reported data, and analyze the differences. By comparing the two it may lend credence to both the employee pay satisfaction process and to discern whether individuals with certain personality traits have the tendency to have a different fairness perception than their supervisor.

There is a critical need for future research efforts to analyze more specific aspects of employee satisfaction. The model that was built and instrument used took a general look at pay satisfaction. It would be beneficial to compare a similar model with a full analysis of pay satisfaction from a comparative perspective. Comparisons can be made for benefit satisfaction, salary satisfaction, pay raise satisfaction and any other dimensions of pay that researchers feel impact employee job satisfaction and productivity. Mount, Barrick and Ryan (2003) suggested that researchers study personality and the fields in which they are most interested. Williams, McDaniel and Nhung (2006) also cautioned that personality should be included in future pay satisfaction research. It is hopeful that more of these additional avenues will be pursued.

Future research efforts should focus on different types of employee work groups. The sample respondents for this study consisted of blue collar workers. Future research efforts should address the significance of personality and pay satisfaction sampling white collar workers. Also, comparative studies should be encouraged. That is, to look at the significance of personality and pay satisfaction of blue collar vs. white collar workers in similar and different industries.

\section{Conclusion}

This study was directed toward understanding whether personality had any significant relationships with pay satisfaction. The results have indicated that personality can be an important variable for the compensation literature and warrants further analysis. It is hoped that the study findings reported herein will stimulate replication and future pay satisfaction and personality research efforts from a broader perspective with larger sample sizes and diverse work groups.

\section{References}

Adams, J. (1963a). Wage inequities, productivity, and work quality. Industrial Relations, 3(1), 9-16. http://dx.doi.org/10.1111/j.1468-232X.1963.tb00805.x 
Adams, J. (1963b). Toward an understanding of inequity. Journal of Abnormal \& Social Psychology, 67(5), 422-436. http://dx.doi.org/10.1037/h0040968

Adams, J. (1965). Inequity in social exchange. In L. Berkowitz (Eds.), Advances in experimental social psychology (pp.267-299). New York: Academic Press.

Adler, S., \& Weiss, H. M. (1988). Recent developments in the study of personality and organizational behavior. In C. L. Cooper, \& I. T. Robertson (Eds.), International review of industrial and organizational psychology (pp. 307-330). Oxford: John Wiley \& Sons.

Antoni, C. H., \& Syrek, C. J. (2012). Leadership and pay satisfaction. International Studies of $\begin{array}{llll}\text { Management } \quad \& \quad \text { Organizations, } & \text { 42(1), }\end{array}$ http://dx.doi.org/10.2753/IMO0020-8825420105

Baker, P. (2007). The relationship between the congruence of physician compensation plan components and physician satisfaction. (Doctoral dissertation). Retrieved from ProQuest Dissertations and Theses. (UMI No. 3278266)

Brandon, G. (1992). A test of modified discrepancy theory: Understanding compensation satisfaction. (Doctoral dissertation). Retrieved from ProQuest Dissertations and Theses. (UMI No. 9226654)

Branson, R. (2010). Your people are your best assets - Celebrate them. Canadian Business, 83(4), 9-9.

Clark, J. (1958). A preliminary investigation of some unconscious assumptions affecting labor efficiency in eight supermarkets. (Unpublished doctoral dissertation). Harvard University, Cambridge, MA.

Cowherd, D. M., \& Levine, D. I. (1992). Product quality and pay equity between lower-level employees and top management: An investigation of distributive justice theory. Administrative Science Quarterly, 37(2), 302-320. http://dx.doi.org/10.2307/2393226

DeGieter, S., DeCooman, R., Hofmans, J., Pepermans, R., \& Hegers, M. (2012). Pay-level satisfaction and psychological reward satisfaction as mediators of the organizational justice-turnover intention relationship. International Studies of Management \& Organizations, 42(1), 50-67.

Digman, J. M. (1997). High-order factors of the big five. Journal of Personality \& Social Psychology, 73(6), 1246-1256.

Dudley, N. M., Orvis, K. A., Lebiecki, J. E., \& Cortina, J. M. (2006). A meta-analytic investigation of conscientiousness in the prediction of job performance: Examining the intercorrelations and the incremental validity of narrow traits. Journal of Applied Psychology, 19(1), 40-57. http://dx.doi.org/10.1037/0021-9010.91.1.40

Dulebohn, J. H., \& Werling, S. E. (2007). Compensation research past, present and future. Human Resource Management Review, 17(2), 191-207. http://dx.doi.org/10.1016/j.hrmr.2007. 03.002 
Gerhart, B., \& Milkovich, G. T. (1992). Employee compensation: Research and practice. In M. D. Dunnette, \& L. M. Hough (Eds.), Handbook of industrial and organizational psychology (pp. 481-569). Palo Alto: Consulting Psychologists Press.

Gerhart, B., \& Rynes, S. (2003). Compensation: Theory, evidence and strategic implications. Thousand Oaks: Sage Publications.

Hair, J. F., Black, W. C., Babin, B. J., \& Anderson, R. E. (2010). Multivariate data analysis. Upper Saddle River: Prentice-Hall.

Heineck, G. (2011). Does it pay to be nice? Personality and earnings in the United Kingdom. Industrial \& Labor Relations Review, 64(5), 1020-1038.

Heneman, H., \& Judge, T. (2000). Compensation attitudes: A review and recommendations for future research. In S.L. Rynes, \& B. Gerhard (Eds.), Compensation in organizations: Progress and prospects (pp. 61-103). San Francisco: Jossey-Bass.

Heneman, H., \& Schwab, D. (1979). Work and rewards theory. In D. Yoder, \& H.G. Heneman Jr. (Eds.), ASPA handbook of personnel and industrial relations (pp. 6.1-6.22.). Washington DC: Bureau of National Affairs.

Heneman, H., \& Schwab, D. (1985). Pay satisfaction: Its multidimensional nature and measurement. International Journal of Psychology, 20(2), 129-141. http://dx.doi.org/10.1080/00207598508246743

Herzberg, F. (1966). Work and the Nature of Man. Cleveland: World Publishing.

Homans, G. C. (1961). Social behavior: Its elementary forms. Oxford: Harcourt, Brace.

Hulkko-Nyman, K., Sarti, D., Hakonen, A., \& Sweins, C. (2012). Total rewards perceptions and work engagement in elder-care organizations. International Studies of Management \& Organization, 42(1), 24-49. http://dx.doi.org/10.2753/IMO0020-8825420102

Judge, T. (1993). Validity of the dimensions of the pay satisfaction questionnaire: Evidence of differential prediction. Personnel Psychology, 46(2), 331-355. http://dx.doi.org/10.1111/j.1744-6570.1993.tb00877.x

Kirkland, S. D. (2009). Compensation plans that pay back. Business \& Economic Review, 55(2), 22-23.

Lawler, E. (1971). Pay and organizational effectiveness. New York: McGraw Hill.

Lopes, H. (2011). Why do people work? Individual wants versus common goods. Journal of Economic Issues, 45(1), 57-74. http://dx.doi.org/10.2753/JEI0021-3624450104

Mount, M., Barrick, M., \& Ryan, M. (2003). Research themes for the future. In M.R. Barrick, \& A.M. Ryan (Eds.), Personality and work: Reconsidering the role of personality in organizations (pp. 326-344). San Francisco: Jossey-Bass.

Mueller, G., \& Plug, E. (2006). Estimating the effect of personality on male and female earnings. Industrial \& Labor Relations Review, 60(1), 3-22. 
Penney, L. M., David, E., \& Witt, L. A. (2011). A review of personality and performance: Identifying boundaries, contingencies, and future research directions. Human Resource Management Review, 21(4), 297-310. http://dx.doi.org/10.1016/j.hrmr.2010.10.005

Pfeffer, J., \& Davis-Blake, A. (1992). Salary dispersion, location in the salary distribution, and turnover among college administrators. Industrial and Labor Relations Review, 45(4), 753-763. http://dx.doi.org/10.2307/2524591

Pfeffer, J., \& Langston, N. (1993). The effect of wage dispersion on satisfaction, productivity, and working collaboratively: Evidence from college university faculty. Administrative Science Quarterly, 38(3), 382-407. http://dx.doi.org/10.2307/2393373

Rice, R. W., Phillips, S. M., \& McFarlin, D. B. (1990). Multiple discrepancies and pay satisfaction. Journal of Applied Psychology, 75(4), 386-393. http://dx.doi.org/10.1037//0021-9010.75.4.386

Shaw, J. D., Duffy, M. K., Jenkins, G. D, \& Gupta, N. (1999). Positive and negative affect, signal sensitivity, and pay satisfaction. Journal of Management, 25(2), 189-205. http://dx.doi.org/10.1016/S0149-2063(99)80009-9

Smola, K. (2003). Incorporating individual-difference, monetary-based constructs into a multi-dimensional pay satisfaction model. (Doctoral dissertation). Retrieved from ProQuest Dissertations and Theses. (UMI No. 3095815)

Spurk, D., \& Abele, A. (2011). Who earns more and why? A multiple mediation model from personality to salary. Journal of Business Psychology, 26(1), 87-103. http://dx.doi.org/10.1007/s10869-010-9184-3

Sum, A., Khatiwada, I., McLaughlin, J., \& Palma, S. (2010). The great recession of 2008-2009 and the blue-collar depression. Challenge, 53(4), 6-24. http://dx.doi.org/10.2753/0577-5132530401

Thompson, D. (1997). A study of equity sensitivity and its relationship to distributive justice, job satisfaction, and pay satisfaction in a team environment. (Doctoral dissertation). Retrieved from ProQuest Dissertations and Theses. (UMI No. 9804471)

Turnasella, T. (2002). Pay and personality. Compensation \& Benefits Review, 34(2), 49-59. http://dx.doi.org/10.1177/0886368702034002008

U.S. Bureau of Economic Analysis. (2012). National income and product account tables. Retrieved on December 11, 2012, from http://www.bea.gov/bea/dn/nipaweb.

Vandenberghe, C., \& Tremblay, M. (2008). The role of pay satisfaction and organizational commitment in turnover intentions: A two-sample study. Journal of Business \& Psychology, 22(3), 275-286. http://dx.doi.org/10.1007/s10869-008-9063-3

Vroom, V. H. (1964). Work and motivation. San Francisco, CA: Jossey-Bass.

Walster, E., Walster, W., \& Berscherid. (1978). Equity theory and research. Boston: Allen and Bacon. 


\section{Macrothink}

Journal of Management Research ISSN 1941-899X 2014, Vol. 6, No. 4

Williams, M., McDaniel, M., \& Ford, L. (2007). Understanding multiple dimensions of compensation satisfaction. Journal of Business and Psychology, 21(3), 429-459. http://dx.doi.org/10.1007/s10869-006-9036-3

Williams, M., McDaniel, M., \& Nhung, N. (2006). A meta-analysis of the antecedents and consequences of pay level satisfaction. Journal of Applied Psychology, 91(2), 392-413. http://dx.doi.org/ 10.1037/0021-9010.91.2.392 